\title{
Immunological Defense Role of Oral Mucosa against Candidiasis Isolated from Human and Domestic Cats Teeba Muthana Mohammed (BDS,MSc) ${ }^{1}$, Amer Khazaal Al-azzawi $(\mathrm{PhD})^{2}$ and Walaa Najm Abood $(\mathrm{PhD})^{3}$ \\ Abstract
}

Background: Candida albicans (C. albicans) is an opportunistic fungus that infects the mucosa of oral cavity. Oral candidiasis remains one of the most common forms of Candida infections.

Objective: To isolated C. albicans from oral cavity of human and cats and study which one was more virulence.

Patients and Methods: C. albicans was collected by swabbing samples from oral mucosa to human and domestic cats. Mice injected with C. albicans isolated from human and cat divided to groups to study the immunological role. For each groups were divided depends of the time subjected to blood serum and tissue biopsy collected (6, 24 hours and 10 days) after mice injected with Candida. Measured IL-17, HMGB1 and G-CSF level in blood samples and tissue biopsy were done.

Results: The concentration of IL-17 in a group of mice injected with isolated Candida from mouth of human showed a significant increase in the two times of draw ( $24 \mathrm{~h}$ and 10 days), while the concentration of IL-17 in group of mice injected with isolated Candida from mouth of cat showed significant increase and this elevation was shown in the two times of tissue biopsy collection ( $6 \mathrm{~h}$ and 24h). While the higher increase in the levels of serum HMGB-1 recorded in mice at $6 \mathrm{~h}$ and $24 \mathrm{~h}$ after injected with isolated Candida from mouths of cats. On another hand the result of the concentration of G-CSF in tissue biopsy showed decreased at 10 days compared with control group.

Conclusion: Candida isolated from human more virulence form Candida isolated from.

Keywords: Candida albicans, IL-17, HMGB1 and G-CSF.

Corresponding Author: teebamuthana5@gmail.com

Received: $13^{\text {th }}$ November 2019

Accepted: $28^{\text {th }}$ November 2019

DOI:https://doi.org/10.26505/DJM.18025061113

\footnotetext{
${ }^{1,2}$ Microbiology Department-College of Veterinary Medicine-University of Diyala - Diyala -Iraq

${ }^{3}$ College of Medicine-University of Diyala - Diyala -Iraq
}

\section{Introduction}

The oral cavity is a place where many better habit to grow different microorganisms lived in as viruses, bacteria, microorganisms. This microorganism could fungus, and protozoa. These areas provide a cause disease, when it has the opportunities 
[1]. One of the microorganisms C. albicans lived normally in mouth, upper respiratory tract, female genital tract and gastrointestinal tract, do not cause disease [2]. Oral candidiasis is the disease that caused by opportunity C. albicans. The Oral candidiasis lesion differs in size, colour and shape in oral cavity. It can cause superficial and serious systemic disease in immune comprised patients [3]. Pathogenicity of C. albicans relies on successful production of virulence factors Virulence factors are responsible for the transformation of $\mathrm{C}$. albicans to causing a disease (pathogen) and makes it possible for C. albicans to survive, persist within the host and cause disease when the opportunity arises $[4,5]$. The skin surface is a unique position, harboring a distinct groups of bacteria and fungi. From important fungi, C. albicans causes cutaneous lesions with the thickening, hyperkeratosis, and erythema of the skin [6,7]. Presence of fungi on the skin lead to interact with keratinocytes, dendritic cells (DCs), and macrophages, as well as with myeloid cells [8].C . albicans can caused a common mucosal infection in vagina worldwide, which called Vulvovaginal candidiasis (VVC) this disease characterized by itching, burning, pain, redness of the vulva and vaginal mucosa, and discharge [9]. Neutrophils play an essential role during VVC immunopathology. Also, studies have showed that neutrophils have an essential immunoregulatory role by releasing important cytokines, such as IL-10 and IL12, to help antifungal $\mathrm{T}$ cell development. Aims of study was isolated C. albicans from oral cavity for human and cats and comparative density of infection between infected mice with human $\mathrm{C}$.albicans isolated and cats C. albicans isolated by examination the histopathological changing and the level of IL-17, HMGB-1 and G-CSF to evaluated which isolated more virulence.

\section{Patients and Methods}

\section{Study Samples}

C. albicans was collected from December 2018- February 2019 through swabing samples from human oral mucosa and domestic cat's oral mucosa. The samples were obtained from the archives of the Department of Oral Diagnosis / College of Veterinary Medicine / Diyala University / private laboratories / Private dental center, Baquba.

\section{Sample collection and candida albicans isolation}

These samples collected from human between (19-30) age old,from the tongue and sub mucosa was been taken to the lab, to be cultured on Sabouraud agar (SAD) incubation for $24 \mathrm{hr}$. at $37 \mathrm{c}$ for Candida albicans isolation. And the samples collected from cats, from the tongue and sub mucosa was been taken to the lab, to be cultured on Sabouraud agar (SAD) incubation for $24 \mathrm{hr}$. at $37 \mathrm{c}$ for $\mathrm{C}$. albicans isolation.

\section{Isolation of Candida albicans}

Inoculated the sample from human and cat in the Sabouraud dextrose agar, after that incubated by using incubator for $24 \mathrm{hr}$ in $37^{\circ} \mathrm{C}$ was to get $\mathrm{C}$. albicans isolate.

Germ tube test: formed of germ tube was done by inoculation of five hundred micro 
liters of human serum and incubation the inoculum two and half hours at $37^{\circ} \mathrm{C}$. Then centrifuged the mixture, removed supernatant and reconstituted the cell precipitate with 500 $\mathrm{uL}$ distilled water. Take a drop of suspension, put on the clean slide, covered with cover slide and examined under 10X and 40X power for detection of germ tube [10]. Induction of inflammation by Candida albicans

This experiment was performed by using laboratory mice from (Iraqi Center for Cancer and Medical Genetics Research/ Unit of Animals House). The mice were divided in to seven groups each group contains 6 mice. First group was normal mice without infection (control group), the second, third, and four groups were injected in oral cavity in a depth $1 \mathrm{~mm}$ with solution of $1 \mathrm{ml} / 10$ - cell of C. albicans isolated from human. While the fifth, sixth, and seventh groups were injected in oral cavity in a depth of $1 \mathrm{~mm}$ with solution $1 \mathrm{ml} / 10$ - cell of $\mathrm{C}$. albicans isolated from cat. The mice in the second and fifth groups were anesthesia by diethyl ether after 6 hours from injection third, sixth groups were anesthesia after 24 hours after injection and fourth and seventh groups were anesthesia after 7 days from injection to collected oral biopsy each mouse are stored in phosphate buffer solution (PBS). Blood sample also collected from each mouse from heart puncture Was collected in tube centrifuged for 20 minutes at 2000 - 3000 rpm) then aspirated serum in new tube and preserved at $-20^{\circ} \mathrm{C}$ till used.

\section{Tissue samples and Homogenization}

After cutting tissue samples from the oral mucosa and lip of the mice, checked the weight $(1 \mathrm{~g})$ added to $10 \mathrm{~mL}$ for PBS, added $0.5 \mathrm{~mL}$ trypsin, maintained samples, homogenized by mortar and pestle. Centrifuged the homogenization for 20 -min at the speed of $2000-3000 \mathrm{rpm}$ removed supernatant and preserved in $-20 \mathrm{c}$ for detection of cytokines.

\section{Mouse (IL-17) ELISA Kit}

The detection of mouse IL-17 by using ELISA kit from SunRed Company (Catalogue No.201-02-0042) the methods was done depend on manufacture instruction.

\section{Mouse (HMGB-1) ELISA Kit}

The detection of mouse HMGB-1 by using ELISA kit from Sunred Company (Catalogue no.201-02-0524) the methods was done depend on manufacture instruction.

\section{Mouse (G-CSF) ELISA kit}

The detection of mouse (G-CSF) ELISA kit from Sunred Company (Catalogue no.20102-0642) the methods was done depend on manufacture instruction.

\section{Tissue preparation}

Mice were euthanized at various time (6hr. ,24 hr. ,10days) during the course of the experiment for pathological observation of tissues. After that the heads of animals were dissected and tissue samples (4-6mm thick) from the oral mucosa and lips were extracted and immediately immersed in the $10 \%$ fixative formalin solution for $24 \mathrm{hr}$ at room temperature to prepare slide for stain by hematoxylin and eosin (H\&E). The sections were examined by light microscopy and 
photomicrographs were taken of each section.

\section{Results}

Estimating the concentration of interleukin-17 in studied groups relative to the times of blood collection

The results of IL-17 showed a significant elevation at $(\mathrm{P} \leq 0.05)$ in all three times of the draw (6h, 24h and 10 days) in a group of mice injected with isolated Candida from mouth of human compared with the control group at (mean $\pm \mathrm{SD}$ ): $(458.49 \pm 112.61$, $543.35 \pm 65.12$ and $391.86 \pm 168.52) \mathrm{pg} / \mathrm{mL}$ respectively. While in control group it was

Table (1): The level of IL-17 in serum of mice injected with Candida isolated from human and cats

\begin{tabular}{|c|c|c|c|}
\hline Groups & Time & No. & $\begin{array}{l}\mathrm{IL}-17 \\
\mathrm{pg} / \mathrm{ml}\end{array}$ \\
\hline Control & IL-17 serum & 6 & $26.37 \pm 28.88$ \\
\hline \multirow{3}{*}{$\begin{array}{c}\text { Candida isolated from } \\
\text { Human }\end{array}$} & 6 hours & 6 & $458.49 \pm 112.61 *$ \\
\hline & 24 hours & $\bar{~} 6$ & $543.35 \pm 65.12 *$ \\
\hline & 10 days & 6 & $391.8 \pm 168.52 *$ \\
\hline \multirow{3}{*}{$\begin{array}{c}\text { Candida isolated from } \\
\text { Cat }\end{array}$} & 6 hours & 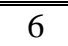 & $182.6 \pm 186.61$ \\
\hline & 24 hours & 6 & $511.5 \pm 30.74 *$ \\
\hline & 10 days & 6 & $493.29 \pm 70.69 *$ \\
\hline
\end{tabular}

*The data was presented at (mean $\pm \mathrm{SD}$ ), the result was

**significant at $(\mathrm{P} \leq 0.05)$ compared with control group

Estimating the concentration of interleukin-17 in studied groups relative to the times of tissue biopsy collection: The results of IL-17 in tissue showed a significant elevation at $(\mathrm{P} \leq 0.05)$ in all three times of draw (6h, $24 \mathrm{~h}$ and 10 days) in group of mice injected with isolated Candida from mouth of human compared with control group at (mean \pm SD): $\quad(402.17 \pm 134.86$, $443.52 \pm 110.23$ and $463.65 \pm 150.83) \mathrm{pg} / \mathrm{mL}$ respectively. While in control group it was (138.2 \pm 134.15$) \mathrm{pg} / \mathrm{mL}$ as shown in Table (2).
$(30.5 \pm 5.53) \mathrm{pg} / \mathrm{ml}$ as shown in Table (1). The concentration of IL-17 in a group of mice injected with isolated Candida from mouth of human (G2) showed a significant increase at $(\mathrm{P} \leq 0.05)$ and this elevation was shown in the two times of draw ( $24 \mathrm{~h}$ and 10 days), while there are statistical differences but non significant at $6 \mathrm{~h}$ of draw compared with the control group at (Mean \pm SD), $(511.59 \pm \quad 30.74, \quad 493.29 \pm 70.69$ and $458.49 \pm 112.61) \mathrm{pg} / \mathrm{ml}$ respectively as shown in Table (1). 
Table (2): The level of IL-17 in tissue of mice injected with Candida isolated from human and cats

\begin{tabular}{|c|c|c|c|}
\hline Groups & Time & No. & $\begin{array}{l}\mathrm{IL}-17 \\
\mathrm{pg} / \mathrm{ml}\end{array}$ \\
\hline Control & IL-17 tissue & 6 & $138.2 \pm 134.15$ \\
\hline \multirow{3}{*}{$\begin{array}{c}\text { Candida isolated from } \\
\text { Human }\end{array}$} & 6 hours & 6 & $402.17 \pm 134.86 *$ \\
\hline & 24 hours & 6 & $443.52 \pm 110.23 *$ \\
\hline & 10 days & 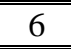 & $463.65 \pm 150.83 *$ \\
\hline \multirow{3}{*}{$\begin{array}{c}\text { Candida isolated from } \\
\text { Cats }\end{array}$} & 6 hours & 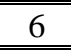 & 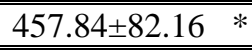 \\
\hline & 24 hours & 6 & $429.73 \pm 215.22 *$ \\
\hline & 10 days & 6 & $48.43 \pm 75.29$ \\
\hline
\end{tabular}

*The data was presented at (mean $\pm \mathrm{SD})$, the result was *significant at $(\mathrm{P} \leq 0.05)$ compared with control group

Estimating the concentration of HMGB-1 in studied groups relative to the times of blood collection: The results showed that the levels of serum HMGB-1 increased significantly $(\mathrm{P} \leq 0.05)$ in all three times of draw (6h, 24h and 10 days) in groups of mice injected with isolated Candida from mouths of both human and cats compared with control group at (mean \pm SD):( $519.72 \pm 160.17, \quad 490.97 \pm 247.75 \quad$ and $546.02 \pm 166.08) \mathrm{ng} / \mathrm{mL}$ respectively in first group. While the higher increase in the levels of serum HMGB-1 recorded in mice at $6 \mathrm{~h}$ and $24 \mathrm{~h}(636.41 \pm 321.04$ and 616.69 \pm 240.26 )ng/mL after injected with isolated Candida from mouths of cats as shown in Table (3).

Table (3): The level of HMGB1in serum of mice injected with Candida isolated from human and cats

\begin{tabular}{|c|c|c|c|}
\hline Groups & Time & No. & $\begin{array}{c}\mathrm{HMGB} 1 \\
\mathrm{ng} / \mathrm{ml}\end{array}$ \\
\hline Control & HMGB1 serum & 6 & $371.81 \pm 162.27$ \\
\hline \multirow{3}{*}{$\begin{array}{c}\text { Candida isolated fro } \\
\text { Human }\end{array}$} & 6 hours & 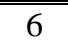 & 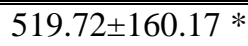 \\
\hline & 24 hours & 6 & $490.97 \pm 247.75 *$ \\
\hline & 10 days & $\overline{6} 6$ & 546.02 $\pm 166.08 *$ \\
\hline \multirow{3}{*}{$\begin{array}{c}\text { Candida isolated fro } \\
\text { Cats }\end{array}$} & 6 hours & 6 & $636.41 \pm 321.04 *$ \\
\hline & 24 hours & 6 & $616.69 \pm 240.26 *$ \\
\hline & 10 days & 6 & $444.13 \pm 201.70 *$ \\
\hline
\end{tabular}

*The data was presented at (mean $\pm \mathrm{SD}$ ), the result was

**significant at $(\mathrm{P} \leq 0.05)$ compared with control group

Estimating the concentration of HMGB-1 in studied groups relative to the times of tissue biopsy collection: The results showed that the levels of HMGB-1in tissue increased significantly $(\mathrm{P} \leq 0.05)$ in all three times of tissue biopsy collection (6h, 24h and 10 days) in groups of mice injected with isolated Candida from mouths of both human and cats compared with control group at (mean \pm SD) and the higher increase in the levels of serum HMGB-1 recorded in mice at $6 \mathrm{~h}$ (624.35 \pm 69.89$) \mathrm{ng} / \mathrm{ml}$ after injected with isolated Candida from mouths of human as shown in Table (4). While In the control group was( $303.35 \pm 153.25) \mathrm{ng} / \mathrm{ml}$. 
Table (4): The level of HMGB1in tissue of mice injected with Candida isolated from human and cats

\begin{tabular}{|c|c|c|c||}
\hline \multicolumn{1}{|c|}{ Groups } & Time & No. & $\begin{array}{c}\text { HMGB1 } \\
\text { ng/ml }\end{array}$ \\
\hline \hline Control & HMGB1 tissue & 6 & $303.35 \pm 153.25$ \\
\hline \hline $\begin{array}{c}\text { Candida isolated from } \\
\text { Human }\end{array}$ & 6 hours & 6 & $624.35 \pm 69.89^{*}$ \\
\cline { 2 - 4 } & 24 hours & 6 & $447.14 \pm 146.28^{*}$ \\
\hline \hline $\begin{array}{c}\text { Candida isolated from } \\
\text { Cats }\end{array}$ & 10 days & 6 & $366.34 \pm 32.73^{*}$ \\
\cline { 2 - 4 } & 6 hours & 6 & $484.12 \pm 88.90^{*}$ \\
\cline { 2 - 4 } & 24 hours & 6 & $432.08 \pm 100.59^{*}$ \\
\hline
\end{tabular}

*The data was presented at (mean $\pm \mathrm{SD}$ ), the result was

**significant at $(\mathrm{P} \leq 0.05)$ compared with control group

Estimating the concentration of G-CSF in studied groups relative to the times of blood collection: Concentration of G-CSF in serum showed significant increasing at $(\mathrm{P} \leq$ $0.05)$ in all three times of draw $(6 \mathrm{~h}, 24 \mathrm{~h}$ and 10 days) and this increasing was more reliable at $6 \mathrm{~h}(1359.29 \pm 1031.9) \mathrm{ng} / \mathrm{L}$ after injected with isolated Candida from mouths of human, also at $24 \mathrm{~h}(920.09 \pm 545.49)$ $\mathrm{ng} / \mathrm{L}$ after injected with isolated Candida from mouths of cats compared with control group $(84.77 \pm 92.86) \mathrm{ng} / \mathrm{L}$ as shown in Table (5).

Table (5): The level of G-CSF in serum of mice injected with Candida isolated from human and cats

\begin{tabular}{|c|c|c|c|}
\hline Groups & Time & No. & $\begin{array}{c}\text { G-CSF } \\
\text { ng/L }\end{array}$ \\
\hline Control & G-CSF in serum & 6 & $84.77 \pm 92.86$ \\
\hline \multirow{3}{*}{$\begin{array}{c}\text { Candida isolated from } \\
\text { Human }\end{array}$} & 6 hours & 6 & $1359.29 \pm 1031.9 *$ \\
\hline & 24 hours & 6 & $878.10 \pm 435.82 * *$ \\
\hline & 10 days & 6 & 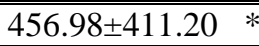 \\
\hline \multirow{3}{*}{$\begin{array}{c}\text { Candida isolated from } \\
\text { Cats }\end{array}$} & 6 hours & 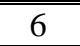 & $877.84 \pm 442.32$ * \\
\hline & 24 hours & 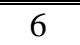 & $920.09 \pm 545.49 *$ \\
\hline & 10 days & 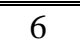 & $657.90 \pm 481.35 *$ \\
\hline
\end{tabular}

*The data was presented at (mean $\pm \mathrm{SD}$ ), the result was

**significant at $(\mathrm{P} \leq 0.05)$ compared with control group

Estimating the concentration of G-CSF in studied groups relative to the times of tissue biopsy collection As shown in table (6), The results referred to insignificant variation $(\mathrm{P} \leq$ $0.05)$ in the concentration of G-CSF at all three times of tissue biopsy collection (6h, $24 \mathrm{~h}$ and 10 days) $(39.07 \pm 85.32$, $130.46 \pm 319.56$ and $39.07 \pm 72.60) \quad \mathrm{ng} / \mathrm{L}$ respectively, in group of mice injected with isolated Candida from mouths of cats. As well as inverse significant variation $(\mathrm{P} \leq$ $0.05)$ in the concentration of G-CSF at two times tissue biopsy collection (6h and $24 \mathrm{~h})($ respectively in group of mice injected with isolated Candida from mouths of human. Whereas the differences were decreased at 10 days $(192.26 \pm 317.59) \mathrm{ng} / \mathrm{L}$ after injection with Candida compared with control group (53.23 \pm 95.76$) \mathrm{ng} / \mathrm{L}$. $844.67 \pm 56$ and $777.48 \pm 577.23) \quad \mathrm{ng} / \mathrm{L}$ 
Table (6): The level of G-CSF in tissue of mice injected with Candida isolated from human and cats

\begin{tabular}{|c|c|c|c|}
\hline Groups & Time & No. & $\begin{array}{c}\text { G-CSF } \\
\text { ng/L }\end{array}$ \\
\hline Control & "G-CSF in tissue & 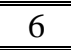 & $53.23 \pm 95.76$ \\
\hline \multirow{3}{*}{$\begin{array}{c}\text { Candida isolated } \\
\text { from } \\
\text { Human }\end{array}$} & 6 hours & 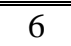 & $8444.67 \pm 56$ \\
\hline & 24 hours & 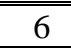 & $777.48 \pm 577.23 *$ \\
\hline & 10 days & 6 & $192.26 \pm 317.59$ \\
\hline \multirow{3}{*}{$\begin{array}{l}\text { Candida isolated } \\
\text { from } \\
\text { Cats }\end{array}$} & 6 hours & 6 & $39.07 \pm 85.32$ \\
\hline & 24 hours & 6 & $130.46 \pm 319.56$ \\
\hline & 10 days & 6 & $39.07 \pm 72.60$ \\
\hline
\end{tabular}

*The data was presented at (mean $\pm \mathrm{SD}$ ), the result was

**significant at $(\mathrm{P} \leq 0.05)$ compared with control group

\section{Histopathological results}

\section{The source of Candida albicans from human smear}

The current study revealed that there was a slight histological changes observed after 6 hours of induced infection with $\mathrm{C}$. albicans obtained from human smear Figure (1); B and B1). These pathological changes manifested by distribution of inflammatory cells at the epidermal layers and mostly observed at the basal layer. The same results were observed after 24 hours but the inflammatory cells were more obvious than the previous one Figure (1); B and B1). However, at day 10 , the results of histopathological changes in oral mucosa of the infected mice indicated there was a visible localization of inflammatory cells (mononuclear cells) were associated with granulomatous inflammation of the epithelium Figure (2); A and A1). This granulomatous lesion and many mononuclear infiltration cells were also observed at the deepest layer of connective tissue attached with hard plate. Additionally, the damaged for the muscle layers were also extended, and many mononuclear cells were observed around these layers Figure (2); B and B1). The results also indicated that the inflammatory cells were also distributed throughout different layers of the degenerated tissue showed a clear damaged for the underlying tissue and separation of the epidermal tissue Figure (2); A and A1). 


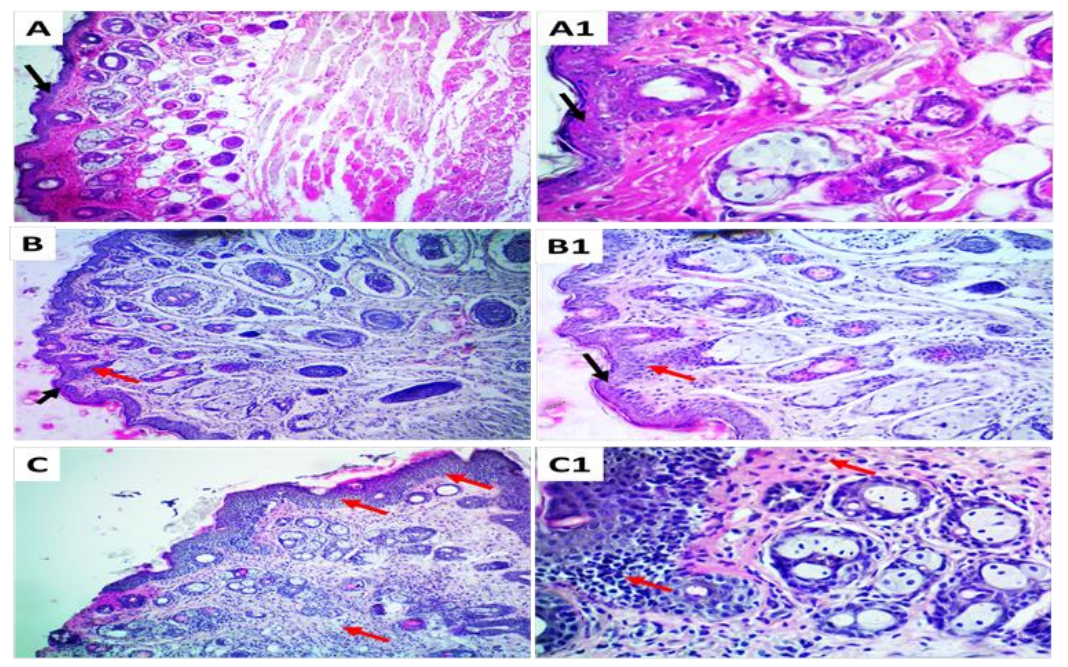

Figure (1): Photomicrographs shows the histopathological observations of oral mucosa induced infection with Candida albicans after 6 hours (B, B1), 24 hours (C, C1), and in normal tissue (A, A1).

(B, B1) sections shows mild inflammatory cells indicated by red arrows, while many of these inflammatory cells were observed in $(\mathrm{C}, \mathrm{C} 1)$ indicated with same red arrows, black arrows shows epidermal tissue were clearly seen in normal tissue (A, A1) did not show any inflammatory cells. (A, B, $\mathrm{C}$, at 10X, while $\mathrm{A} 1, \mathrm{~B} 1, \mathrm{C} 1$ at $40 \mathrm{X})(\mathrm{H} \& \mathrm{E})$.
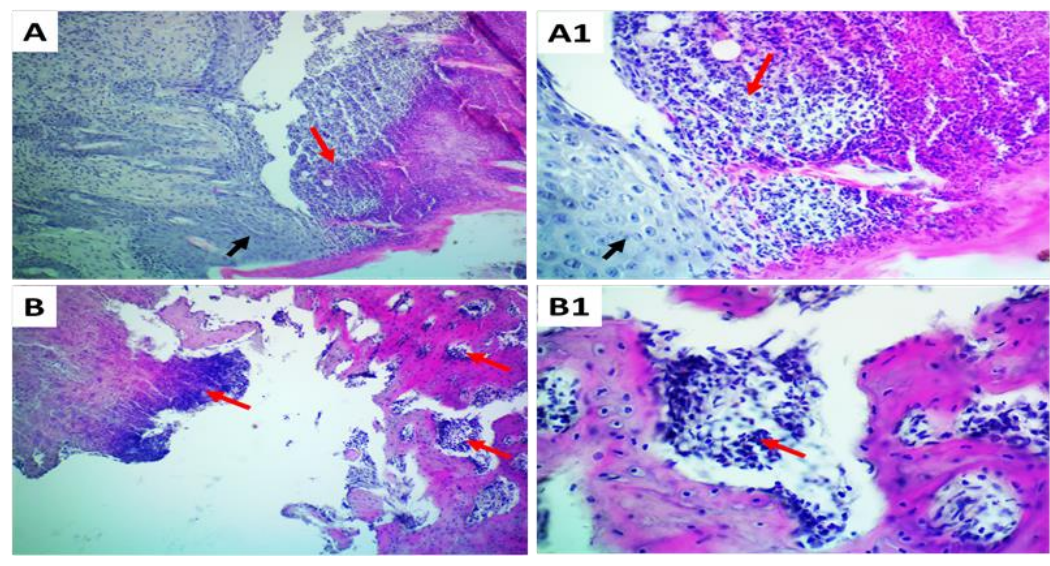

Figure (2): Photomicrographs shows the histopathological observations of oral mucosa induced infection with Candida albicans after 10 days (A, A1), and the inflammation was observed deeply to underlying tissue and close to hard palate (B, B1). (A, A1) sections shows granulomatous inflammation contained many inflammatory cells indicated by red arrows, while many of these inflammatory were observed in deepest tissue attached to the hard palate (B, B1) indicated with same red arrows, black arrows shows epidermal tissue. (A, B, at 10X, while A1, B1, at 40X) (H\&E). 


\section{The source of Candida albicans from cat} smear

The second group infected with Candida albicans obtained from cat smear were indicated the same histopathological results observed after 6 hours of induced infection Figure (3); A and A1). These histopathological changes showed mild inflammatory cells at the epidermal layers and mainly observed at the basal and suparbasal layer. The same results were detected after 24 hours but the inflammatory cells were more obvious than the previous one Figure (4). However, at day 10, the results of histopathological changes in oral mucosa of the infected mice indicated there was a visible localization of inflammatory cells (mononuclear cells) were associated with granulomatous inflammation of the epithelium. This granulomatous lesion and many mononuclear infiltration cells were also observed at deepest layer of connective tissue and reached to the attachment with hard palate. Additionally, the damaged for the muscle layers were also extended, and many mononuclear cells were observed around these layers. The inflammatory cells were also distributed throughout different layers of the tissue causes a clear degeneration and separation of the epithelial tissue Figure (4); B and B1).

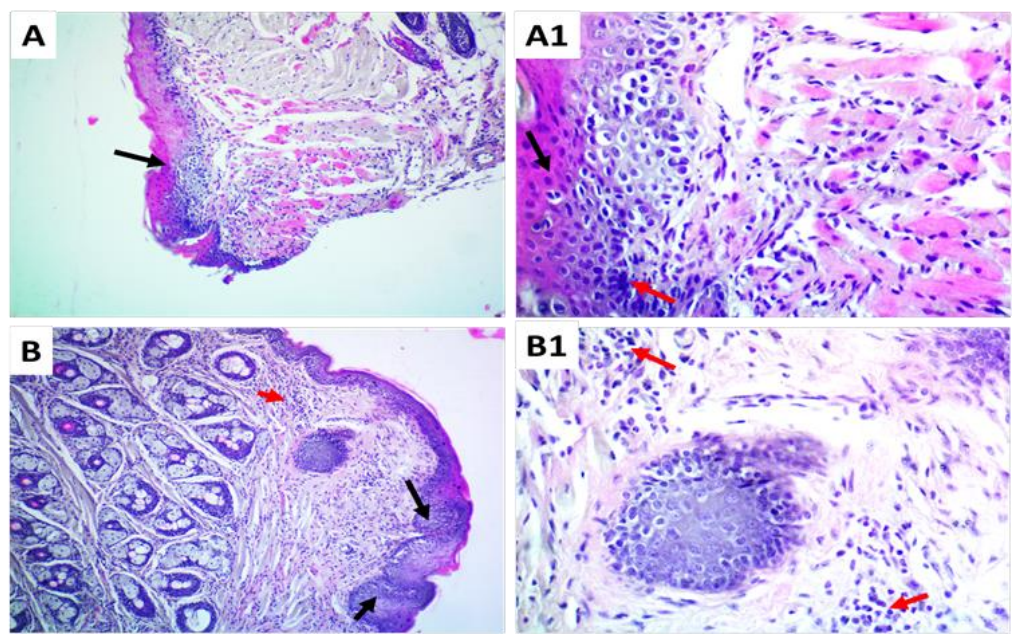

Figure (3): Photomicrographs shows the histopathological observations of oral mucosa induced infection with Candida albicans after 6 hours (A, A1), 24 hours (B, B1). (A, A1) sections shows mild inflammatory cells indicated by red arrows, while many of these inflammatory were observed in (B, B1) indicated with same red arrows, black arrows shows epidermal tissue. (A, B at 10X, while A1, B1 at 40X) (H\&E) 


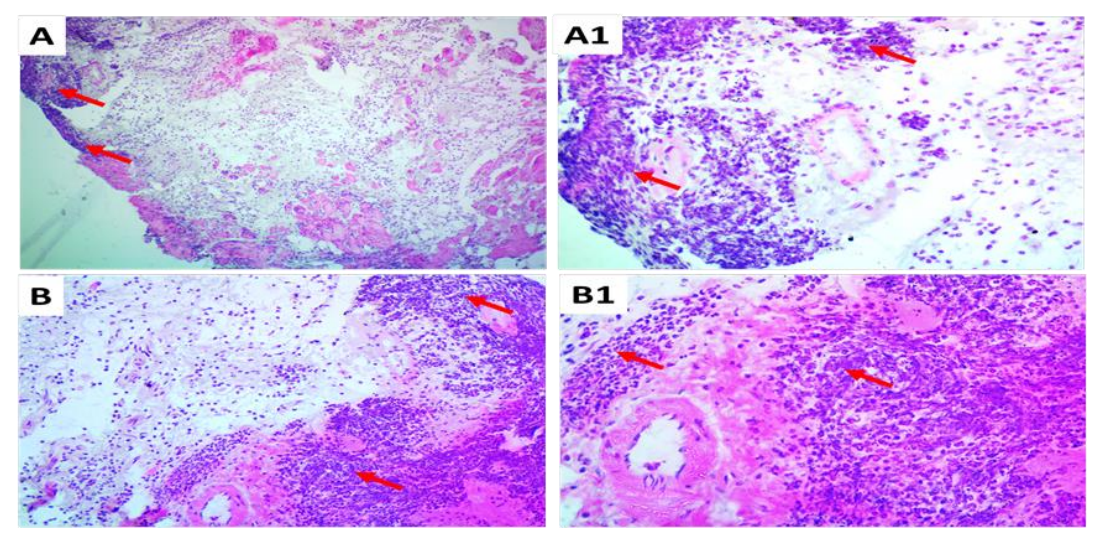

Figure (4): Photomicrographs shows the histopathological observations of oral mucosa induced infection with Candida albicans after 10 days (A, A1), and the inflammation was observed distributed throughout the tissue (B, B1). (A, A1) sections shows granulomatous inflammation contained many

inflammatory cells indicated by red arrows, while many of these inflammatory were observed distributed throughout the muscle (B, B1), these cells were indicated with red arrows. (A, B at 10X, while $\mathrm{A} 1, \mathrm{~B} 1$ at $40 \mathrm{X})(\mathrm{H} \& \mathrm{E})$

\section{Discussion}

There are significant increases in amount of IL-17 in both, collected blood samples and tissue biopsies, and specially $6 \mathrm{~h}$ and $24 \mathrm{~h}$ Post infection. Many studies have mentioned that many defense mechanisms were included in response to candidiasis, and IL17 is the most strongly recommended in such immune response [11]. It was reported that IL-17 and INF- $\gamma$ play an important roles in protection against fungal infections, when they effectively enhanced neutrophils and macrophages in killing of fungi during the innate responses of the host .The importance of IL-17 extended to candidiasis in systemic infection, and this was attributed to the fact that laboratory mice are more susceptible to candidiasis when compared to the mice of wild type. The laboratory mice showed significant increases of IL-17 A2/2 and ILRA2/2 [12,13,14]. Using of C. albicans vaccines showed protective responses experimentally and produced both Th17 and Th1 the most effective cells against candidiasis [16].High mobility group box-1 (HMGB-1) protein showed significant increase during the three selected times $(6 \mathrm{~h}$, $24 \mathrm{~h}$, and 10 days) PI when samples were collected from blood or tissue biopsies. These findings come in agreement with many studies worldwide. Many immune cells were reported to secret HMGB-1, including dendritic cells, macrophages and monocytes as a cytokine for the mediation of inflammation $[17,18]$. Binding of HMGB-1 to TLR2 and TLR4 will mediate the activation of macrophages to release cytokines during inflammatory responses $[19,20]$. HMGB-1 can bind to receptor for advanced glycation end products (RAGE) when released from cells and mediate the inflammation process [21]. Neutralization of HMGB-1 by circulating antibodies aided in relief of damaged tissues. Upregulation of 
$\mathrm{NF}-\kappa \mathrm{B}$ was mediated by the interaction between TLR4 and HMGB-1. This upregulation increased cytokines secretion by many immune cells and also stimulate neutrophils to produce NADPH oxidase that was essential for the production of reactive oxygen species[22].

Granulocyte colony-stimulating factor in present study showed significant increase in both blood and biopsy tissue samples when compared to that of control. Such a relationship would suggest that G-CSF functions in a feedback relationship similar to erythropoietin and the endocrine hormones. It can be inferred on the basis of other studies that such a relationship exists. The repeated injection of dogs with G-CSF from human resulted in formation of antibodies that reacted crossly with G-CSF from dogs [23], the same dogs showed blood pictures of neutropenia lasted for long time and declined with decreased levels of anti G-CSF antibodies in blood circulation. The same results were obtained in dogs injected with plasma with anti G-CSF antibodies. Targeting of G-CSF gene in mice resulted in chronic neutropenia with $20 \%$ to $30 \%$ less than normal mice and lacking G-CSF [24]. It was hypothesized that G-CSF cytokine is essential and critical for the regulation of the neutrophil levels in blood circulation, but acute tissue injury, endotoxin administration and acute infections increased the levels of G-CSF. There is a parallel increase in blood neutrophils, consistent with the hypothesis that this cytokine serves as a long-range stimulus for marrow neutrophil release and increased neutrophil production. Further understanding of the physiologic role of GCSF will require more sensitive immunoassays and more detailed studies of cytokine responses during infectious and inflammatory diseases.

In the current experimental study indicated that the virulence of $\mathrm{C}$. albicans induced a clear damaged to underlying tissue and it was observed extended deeply to reach to the muscle and bone. A possible explanation for these findings may be attributed to the virulence of $\mathrm{C}$. albicans that is represented by having many factors such as, production extracellular hydrolytic enzyme [25], hyphal formation and surface recognition molecules [26]. The present study was also showed a clear differences in histopathological changes throughout the course of the experiment, as it was observed that the degree of damage of oral mucosa in inoculated mice was found to be further severe at day 10 than to other at 1 and 6 days for both isolation from human and cat. These differences can be clarified in part by the formation of granulomatous inflammation on the epithelial tissue after prolonged survival of C. albicans. Comparison these results with those of other studies confirms the formation of granulomatous papillary tissues infiltrate with inflammatory cells [27]. It seems possible that the granulomatous inflammation and thickening in the epithelium are due to increasing the fungal infection over time in most of the epithelial surfaces and induces bacterial infection [25]. Overall, this study compared the virulence among the different 
isolations and may in part be attributed to the local immune responses induced by different isolations.

\section{Conclusions}

The findings of this study was approved that $\mathrm{C}$. albicans occurs as a commensal in the oral cavity of healthy humans and animals. IL-17 is the most strongly recommended in such immune response. High mobility group box-1 (HMGB-1) protein showed significant increase during the three selected times (6h, $24 \mathrm{~h}$, and 10 days) post infection when samples were collected from blood or tissue biopsies. The C. albicans that isolated from human more virulence than $C$. albicans isolated from cat.

\section{References}

[1]Olsen I. Orale infeksjoner. In: Rollag H, editor. Medisinsk mikrobiologi. UNIVERSITY OF OSLO FACULTY OF DENTISTRY. 3 ed(2010). P.697-717.

[2]Q Coronado-Castellote. L, JimenezSoriano Y.(2013), Clinical and microbiological diagnosis of oral candidiasis. Journal of clinical and experimental dentistry.;5(5):e279-e86.

[3]Alka Nerurkar, Priti Solanky, Nilesh Chavda, Hinal Baria, Binita Desai.(2012). Isolation of Candida Species in Clinical Specimens and its Virulence Factor: The Biofilm. Int J Med Sci Public Health, vol.1 (2), 97-100.

[4]Naglik JR1, Challacombe SJ, Hube B.(2003) Candida albicans secreted aspartyl proteinases in virulence and pathogenesis. Microbiol Mol Biol Rev. Sep;67(3):400-28.
[5]Rossoni. R.D., Barbosa, J.O., Vilela, S.F.G., dos Santos, J.D., Jorge, A.O.C.and Jun-queira, J.C.(2013). Correlation of phospholipase and proteinase production of Candida with in vivo pathogenicity in Galleria mellonella Brazilian Journalof Oral Sciences12, 199-204.

[6]Sathishkumar. T.; Scott, J.X.; George, R. (2005). Chronic mucocutaneous candidiasis in a child. Indian J. Dermatol. Venereol. Leprol, 2017 Apr 3;8(3):324-333.

[7]Jo, J.H.; Kennedy, E.A.; Kong, H.H. Topographical and physiological differences of the skin mycobiome in health and disease. Virulence, 8, 324-333.

[8]Chambô Filho A, Souza Filho JB, Pignaton CC, Zon I, Fernandes AS1, Cardoso LQ. (2014) Chronic mucocutaneous candidiasis: a case with exuberant cutaneous horns in nipples. An Bras Dermatol ;89(4):641-4.

[9]Denning, D.W.; Kneale, M.; Sobel, J.D.; Rautemaa-Richardson, R. (2018). Global burden of recurrent vulvovaginal candidiasis: A systematic review. Lancet Infect. Dis, 18, e339-e347.

[10]J. Isibor, A. E. Eghubare, and R. Omoregie, "Germ tube formation in Candida albicans: Evaluation of human and animal sera and incubation atmosphere," Shiraz EMedical journal, vol. 6, pp. 1-2, 2005.

[11]Fidel PL Jr. Candida-host interactions in HIV disease: implications for oropharyngeal candidiasis. Adv Dent Res. 2011 Apr;23(1):45-49.

[12]Huang, W., L. Na, P. L. Fidel, and P. Schwarzenberger. 2004. Requirement of 
interleukin-17A for systemic anti-Candida albicans host defense in mice. J. Infect. Dis. 190: 624-631.

[13]Saijo.S., S. Ikeda, K. Yamabe, S. Kakuta, H. Ishigame, A. Akitsu, N. Fujikado,T. Kusaka, S. Kubo, S. H. Chung, et al. 2010. Dectin-2 recognition of alphamannans and induction of Th17 cell differentiation is essential for host defense against Candida albicans. Immunity 32: 681-691.

[14]Van de Veerdonk, F. L., B. J. Kullberg, I. C. Verschueren, T. Hendriks, J. W. van der Meer, L. A. Joosten, and M. G. Netea. 2010. Differential effects of IL-17 pathway in disseminated candidiasis and zymosaninduced multiple organ failure. Shock 34: 407-411.

[15]Lin L, Ibrahim AS, Xu X, Farber JM, Avanesian V, Baquir B, Fu Y, French SW, Edwards JE Jr, Spellberg B.(2009) Th1-Th17 cells mediate protective adaptive immunity against Staphylococcus aureus and Candida albicans infection in mice PLoS Pathog.Dec;5(12).

[16]Wang H, Bloom O, Zhang M, Vishnubhakat JM, Ombrellino M, Che J, Frazier A, Yang H, Ivanova S, Borovikova L, Manogue KR, Faist E, Abraham E, Andersson J, Andersson U, Molina PE, Abumrad NN, Sama A, Tracey KJ (July 1999). "HMG-1 as a late mediator of endotoxin lethality in mice". Science. 285 (5425): 248-51.

[17]Klune JR, Dhupar R, Cardinal J, Billiar TR, Tsung A (2008). "HMGB1: endogenous danger signaling". Molecular Medicine. 14 (7-8): 476-84.
[18]Yang H, Hreggvidsdottir HS, Palmblad K, Wang H, Ochani M, Li J et al. A critical cysteine is required for HMGB1 binding to Toll-like receptor 4 and activation of macrophage cytokine release. Proc Natl Acad Sci USA 2010; 107: 11942-11947.

[19]Yang H, Tracey KJ (2010). "Targeting HMGB1 in inflammation". Biochimica et Biophysica Acta. 1799 (1-2149-56. [20]Sims GP, Rowe DC, Rietdijk ST, Herbst R, Coyle AJ (2010). "HMGB1 and RAGE in inflammation and cancer". Annual Review of Immunology. 28: 367-88.

[21]Hreggvidsdóttir HS, Lundberg AM, Aveberger AC, Klevenvall L, Andersson U, Harris HE (March 2012). "High mobility group box protein 1 (HMGB1)-partner molecule complexes enhance cytokine production by signaling through the partner molecule receptor". Molecular Medicine. 18: 224-30.

[22]Hammond. WP, Csiba E, Canin A, Souza LM, Dale DC. (1991). Chronic neutropenia: a new canine model induced by human GCSF. J Clin Invest. 10-87:704,1991.

[23] Lieschke GJ, Grail D, Hodgson G, et al. (1994). Mice lacking granulocyte colonystimulating factor have chronic neutropenia, granulocyte and macrophage progenitor cell deficiency, and impaired neutrophil mobilization Blood 1994; 84:1737-46.

[24]Da Silva Dantas, A., Lee, K. K., Raziunaite, I., Schaefer, K., Wagener, J., Yadav, B. \& Gow, N. A. 2016. Cell biology of Candida albicans-host interactions. 
Current opinion in microbiology, 34, 111118.

[25]Zhou, Y., Liao, M., Zhu, C., Hu, Y., Tong, T., Peng, X., Li, M., Feng, M., Cheng, L. \& Ren, B. 2018. ERG3 and ERG11 genes are critical for the pathogenesis of Candida albicans during the oral mucosal infection. International journal of oral science, 10, 9 . [26]Farah, C., Elahi, S., Pang, G., Gotjamanos, T., Seymour, G., Clancy, R. \& Ashman, R. 2001. T cells augment monocyte and neutrophil function in host resistance against oropharyngeal candidiasis. Infection and immunity, 69, 6110-6118.

[27]Bertolini, M., Ranjan, A., Thompson, A., Diaz, P. I., Sobue, T., Maas, K. \& DongariBagtzoglou, A. 2019. Candida albicans induces mucosal bacterial dysbiosis that promotes invasive infection. PLoS pathogens, 15, e1007717. 